\title{
P018: A prospective study of catheter associated urinary tract infections and rationalisation of antibiotic use in a tertiary care centre in North India
}

\author{
N Taneja ${ }^{1 *}$, S Appanwar ${ }^{1}$, M Biswal', B Mohan ${ }^{1}$, MM Aggarwal $^{2}$, R M$^{2}$, AK Mandal $^{2}$ \\ From 2nd International Conference on Prevention and Infection Control (ICPIC 2013) \\ Geneva, Switzerland. 25-28 June 2013
}

\section{Introduction}

Catheter associated bacteriuria is very common and there is a need to differentiate symptomatic CA-UTI from asymptomatic bacteriuria (CA-ASB) to rationalise antibiotic usage.

\section{Objectives}

Aim was to evaluate prevalence of catheter $\mathrm{CA}-\mathrm{ABU} \mathrm{v} / \mathrm{s}$ CA-UTI and to assess the antibiotic usage in CA-ABU and CA-UTI group.

\section{Methods}

A prospective cohort longitudinal study was conducted by recruiting seventy consecutive patients with catheter in situ over a period of three months. Patients were categorized as symptomatic and asymptomatic CAUTI based on the CDC definition. Demographic profile, primary \& other co-morbidities, type of catheter, indication and duration of catheterization, details of surgical procedure performed, antibiotic prophylaxis and therapy were noted. The bed occupancy rate, device utilization rates, total device days and device associated infections (DAI) rate were calculated using standard definitions. Microbiological data were noted and analysed. Data analysed using SPSS-17.

\section{Results}

Out of 70 patients, 52 had bacteriuria of which 10 were symptomatic. Ratio of urinary catheter use was 0.69 . Catheter utilisation rate was 40.29/1000 device days and the rate of CA-UTI was 12.8 /1000 device days. Median duration of hospitalisation was 29 and 30 days for CAASB and CA-UTI. There was nostatistically significant difference between median duration of catheterisation (p value $>0.5$ ). Overall 737 DDDS were given. Though symptomatic patients received more antibiotics the difference from asymptomatic bacteriuria was not significant. Inappropriate antibiotics usage was noted in the form wrong class, 2 antibiotics of same class and wrong indication in many cases.

\section{Conclusion}

Pilot study helped us to rationalize the antibiotic usage in our centre.

\section{Disclosure of interest}

None declared.

\section{Author details}

${ }^{1}$ Medical Microbiology, Chandigarh, India. ${ }^{2}$ AUC, PGIMER, Chandigarh, India.

Published: 20 June 2013

doi:10.1186/2047-2994-2-S1-P18

Cite this article as: Taneja et al: P018: A prospective study of catheter associated urinary tract infections and rationalisation of antibiotic use in a tertiary care centre in North India. Antimicrobial Resistance and Infection Control 2013 2(Suppl 1):P18.

Medical Microbiology, Chandigarh, India

Full list of author information is available at the end of the article

(c) 2013 Taneja et al; licensee BioMed Central Ltd. This is an Open Access article distributed under the terms of the Creative Commons Attribution License (http://creativecommons.org/licenses/by/2.0), which permits unrestricted use, distribution, and reproduction in any medium, provided the original work is properly cited. 